\title{
KEPEMIMPINAN DAN KETERLIBATAN KARYAWAN PT PLN RAYON TALANG PADANG TERHADAP KINERJA KARYAWAN
}

\author{
HERZA KURNIA \\ Universitas Lampung \\ herzakurnia@gmail.com
}

\begin{abstract}
Abstrak. Penelitian ini bertujuan untuk menguji pengaruh kepemimpinan dan keterlibatan karyawan terhadap kinerja karyawan. Data yang digunakan adalah data primer. Adapun teknik pengumpulan datanya digunakan melalui kuisioner. Penelitian ini mangambil data dari seluruh karyawan PT PLN Rayon Talang Padang sebanyak 142 responden. Analisis data yang digunakan untuk melihat hubungan antar variabel melalui uji statistik dan pengolahan data yang dilakukan dengan menggunakan Analisis Regresi Berganda dengan bantuan SPSS 20.0. Hasil penelitian menunjukkan bahwa penelitian ini mendukung hipotesis yang diajukan, yaitu: kepemimpinan berpengaruh positif terhadap keterlibatan karyawan, begitu juga dengan variabel keterlibatan karyawan berpengaruh positif terhadap kinerja karyawan. Hal ini membuktikan bahwa kepemimpinan merupakan faktor yang penting dalam meningkatkan kineja karyawan di tempat bekerja, karena dengan kepemimpinan yang baik dan keterlibatan karyawan dapat mendorong motivasi karyawan dalam meningkatkan kinerja di tempat bekerja.
\end{abstract}

Kata kunci: Kepemimpinan, Keterlibatan dan Kinerja.

\section{LEADERSHIP AND EMPLOYEE INVOLVEMENT OF PT PLN RAYON TALANG PADANG ON EMPLOYEE PERFORMANCE}

\author{
HERZA KURNIA \\ Lampung University \\ herzakurnia@gmail.com
}

\begin{abstract}
This study aims to examine the effect of leadership and employee involvement on employee performance. The data used is primary data. The data collection technique is used through a questionnaire. This study took data from all employees of PT PLN Rayon Talang Padang as many as 142 respondents. Analysis of the data used to see the relationship between variables through statistical tests and data processing performed using Multiple Regression Analysis with the help of SPSS 20.0. The results show that this study supports the proposed hypothesis, namely: leadership has a positive effect on employee engagement, as well as employee involvement variable has a positive effect on employee performance. This proves that leadership is an important factor in improving employee performance in the workplace, because good leadership and employee involvement can encourage employee motivation in improving performance at work.
\end{abstract}

Keywords: Leadership, Engagement and Performance. 


\section{PENDAHULUAN}

Hubungan antara kepemimpinan terhadap kinerja karyawan telah diuji melalui pnelitian yang dilakukan oleh Mehta et al (2013) menyatakan kepemimpinan berpengaruh positif terhadap kinerja karyawan. Sugiyono (2009) menunjukkan bahwa karyawan PT Holcim Indonesia pabrik Cilacap memiliki kesiapan untuk berubah yang tinggi dan hal tersebut dipengaruhi secar positif oleh keterlibatan karyawan dan kepuasan kerja, sedangkan faktor kepemimpinan tidak berpengaruh langsung terhadap kesiapan untuk berubah tetapi melalui variabel intervening yaitu kepuasan kerja dan keterlibatan karyawan.

Listrik merupakan salah satu kebutuhan yang tidak dapat terpisahkan dari kehidupan manusia. PT PLN Rayon Talang Padang merupakan Badan Usaha Milik Negara yangmenangani semua aspek kelistrikan yang ada di Talang Padang. PT PLN (Persero)Rayon Talang Padang sebagai perusahaan yang berada dalam lingkungan bisnis yang semakin dinamis diera globalisasi, dituntut untuk menunjukkan kinerja yang handal dalam memenuhituntutan stakeholder.

Tingkat kebutuhan listrik semakin meningkat setiaptahunnya, karena adanya kenaikan kebutuhan listrik ini tentu saja membuat kayawan juga harusmeningkatkan kinerja serta pelayanan di PT PLN Rayon Talang Padang. Pelayanan sertakinerja yang baik tentu saja akan mengurangi keluhan masyarakat yang sering terjadi, salah satunya adalah keluhan saat terjadi pemadaman listrik.

PT PLN Rayon Talang Padang memiliki karyawan sebanyak 142 orang. Berikut adalah daftar jumlah karyawan PT PLN Rayon Talang Padang.
Jumlah Karyawan Berdasarkan Jabatan Atau

Bagian pada PT. PLN Rayon Talang Padang

Tahun 2018

\begin{tabular}{lll}
\hline NO & BAGIAN & JUMLAH \\
\hline 1 & SDM & 24 \\
2 & KEUANGAN & 19 \\
3 & AREA PENGATUR DISTRIBUSI & 13 \\
4 & HUKUM & 8 \\
5 & NIAGA DAN PELAYANAN & 20 \\
6 & PELANGGAN & 25 \\
7 & DISTRIBUSI & 9 \\
8 & INFORETARIAT DAN UMUM & 9 \\
9 & PERENCANAAN & 15 \\
& TOTAL & $\mathbf{1 4 2}$ \\
\hline
\end{tabular}

Sumber: PT PLN Rayon Talang Padang 2018

Tabel jumlah karyawan yang cukup besar pada PT PLN Rayon Talang Padang dengan banyaknya jumlah karyawan tersebut, perusahaan berharap bisa memberdayakan karyawan dengan maksimal. Kebijakan dan peraturan yang berlaku pada PT PLN Rayon Talang Padang sebagai upaya mengoptimalkan pelayanan tentu saja harrus ditingkatkan supaya kebutuhan listrik tidakterganggu. Kesesuaian kepemimpinan dan keterlibatan karyawan juga harus diperhatikanguna menghasilkan pelayanan yang lebih baik. Observasi yang dilakukan peneliti aspek kepemimpinan yang dilakukan PT PLN Rayon Talang Padang juga masih ditemukan kurangnya kesempatan bawahan untuk memberikan saran dan pendapat, Selain itu kerjasama dalam menyelesaikan masalah yang muncul, serta dinilai masih kurang keharmonisan dan kebersamaan antar staf karena masih cenderung kurang fokus pada tugas masingmasing. Keadaan ini tentunya menjadi permasalahan tersendiri apalagi tugas-tugas sebagian karyawan mengharuskan adanya kerjasama antar tim.Berikut adalah data absensi karyawan PT PLN Rayon Talang Padang Tahun 2018.

Data Absensi Karyawan PT PLN Rayon Talang Padang 2018 


\begin{tabular}{lllll}
\hline Bulan & $\begin{array}{l}\text { Jumlah } \\
\text { Karyawan }\end{array}$ & $\begin{array}{l}\text { Hari } \\
\text { kerja }\end{array}$ & $\begin{array}{l}\text { Jumlah } \\
\text { Absensi }\end{array}$ & $\begin{array}{l}\text { Tingkat } \\
\text { Absensi }\end{array}$ \\
\hline Januari & 142 & 25 & 35 & 0,98 \\
Februari & 142 & 24 & 38 & 1,11 \\
Maret & 142 & 23 & 32 & 0,97 \\
April & 142 & 26 & 48 & 1,30 \\
Mei & 142 & 25 & 45 & 1,26 \\
Juni & 142 & 25 & 49 & 1,38 \\
Juli & 142 & 26 & 40 & 1,08 \\
Agustus & 142 & 24 & 41 & 1,20 \\
September & 142 & 26 & 55 & 1,48 \\
Oktober & 142 & 23 & 65 & 1,99 \\
November & 142 & 24 & 68 & 1,99 \\
Desember & 142 & 23 & 70 & 2,14 \\
Total & & & 16,88 \\
Rata-rata & & &
\end{tabular}

\begin{tabular}{|c|c|c|c|c|}
\hline & $\begin{array}{l}\text { dengan Pendidikan } \\
\text { dan Kompetensi } \\
\text { yang sepadan pada } \\
\text { posisinya }\end{array}$ & $\begin{array}{l}\text { dengan latar } \\
\text { belakang } \\
\text { pendidikan }\end{array}$ & & \\
\hline 7 & $\begin{array}{l}\text { Memberikan } \\
\text { Kesempatan dan } \\
\text { Mengutus personil } \\
\text { yang mampu untuk } \\
\text { mendapatkan } \\
\text { tingkat pendidikan } \\
\text { yang lebih baik } \\
\text { agar hasil kerja dan } \\
\text { karirnya dapat } \\
\text { berkembang }\end{array}$ & $\begin{array}{l}\text { Membuat personil } \\
\text { mendapatkan } \\
\text { tingkat pendidikan } \\
\text { yang lebih baik } \\
\text { untuk melaksanakan } \\
\text { seluruh kegiatan }\end{array}$ & $90 \%$ & $80 \%$ \\
\hline 8 & $\begin{array}{l}\text { Meningkatkan } \\
\text { kompetensi } \\
\text { aparatur melalui } \\
\text { jenjang pendidikan } \\
\text { maupun jenjang } \\
\text { pelatihan }\end{array}$ & $\begin{array}{l}\text { Tingkat penguasaan } \\
\text { pekerjaan masing- } \\
\text { masing aparatur }\end{array}$ & $100 \%$ & $65 \%$ \\
\hline 9 & $\begin{array}{l}\text { Meningkatkan } \\
\text { kualitas produk } \\
\text { jalan berdasarkan } \\
\text { dukungan bahan } \\
\text { dan peralatan }\end{array}$ & $\begin{array}{l}\text { Menjamin hasil } \\
\text { produk yang } \\
\text { terjamin dan } \\
\text { berkualitas }\end{array}$ & $100 \%$ & $80,5 \%$ \\
\hline
\end{tabular}

Tabel menunjukkan bahwa program kegiatan item no 1,2,3, dan 5 termasuk dalam klarifikasi kepemimpinan manajer sedangkan lima program lainnya merupakan program kegiatan mengenai keterlibatan, secara keseluruhan dapat dilihat program kegiatan belum sesuai dengan target yang ingin dicapai. Salah satu capaian terbesar dalam program sosialisasi penyampaian laporan kegiatan yang targetnya tercapai sebesar 85 persen yang tercapai dari target 100 persen dokumen yang ditetapkan. Hal ini tidak terlepas dari peran seorang pemimpin yang selalu melibatkan pegawai dalam diskusi dan pengambilan keputusan,sehingga sosialisasi penyampaian kegiatan ini berjalan dengan baik.

\section{TINJAUAN TEORITIS}

\section{Kepemimpinan}

Perkataan pemimpin atau leader memiliki berbagai pengertian. Pemimpin merupakan dampak interaktif dari faktor individu atau pribadi dengan faktor situasi. Pimpinan merupakan suatu figur yang diteladani oleh para bawahan, anggota atau orang lain, dalam pencapaian suatu tujuan. Oleh karena itu seorang pemimpin harus berperilaku yang baik, jujur, mengayomi dan 
peka terhadap kebutuhan lingkungan serta bergerak dalam satu lingkup teori kepemimpinan.

Kepemimpinan adalah bagian penting manajemen, tetapi tidak sama dengan manajemen. Kepemimpinan merupakan kemampuan yang dipunyai seseorang untuk mempengaruhi orang-orang lain agar bekerja mencapai tujuan dan sasaran (Trisnowati Josiah 2021). Kepemimpinan merupakan hal yang sangat penting dalam menejerial karena kepemimpinan maka proses manajemen dapat berjalan dengan baik sehingga pegawai akan bersemangat dalam melaksanakan tugasnya. (Dharmawan 2020) mendefinisikan kepemimpinan sebagai suatu perilaku dengan tujuan tertentu untuk mempengaruhi aktivitas para anggota kelompok untuk mencapai tujuan bersama yang dirancang untuk memberikan manfaat individu dan organisasi.

\section{Pengertian Keterlibatan Karyawan}

Keterlibatan karyawan adalah keterlibatan seorang karyawan secara psikologis dalam berkomitmen untuk menyelesaikan pekerjaan seseorang (Aprianis 2020). Karyawan yang terlibat (mengalami tingkat konektivitas tinggi dengan tugas kerja mereka), dan oleh karenanya bekerja keras untuk menyelesaikan sasaran terkait tugas mereka. Keterlibatan karyawan penting karena baik perilaku karyawan maupun kinerja organisasi mencerminkan apakah karyawan tersebut (terlibat). (Malayu .S.P. Hasibuan 2013) keterlibatan karyawan sebagai kerja simultan dan ekspresi diri seorang karyawan yang menyukai pekerjaanya adalah perilaku yang menghubungkan pekerjaannya dengan kinerja.

Keterlibatan karyawan dapat diartikan sebagai sebuah proses yang mengikutsertakan para karyawan pada semua level organisasi dalam membuat keputusan untuk memecahkan masalah. Keterlibatan karyawan dianggap sebagai suatu jenis sikap yang berhubungan dengan pekerjaan secara emosional, kognitif dan fisik secara antusias untuk dilakukan karyawan terhadap pekerjaanya (Malayu .S.P. Hasibuan 2001).

Keterlibatan karyawan sangat penting guna mencapai tujuan dari sebuah perusahaan, dengan adanya pelibatan karyawan karyawan akan lebih produktif. Karyawan yang terlibat akan berupaya lebih keras untuk meningkatkan kinerjanya. Menurut (P Stephen \& Coutler Robbins 2016) keterlibatan karyawan yaitu seorang individu, kepuasan, dan antusiasme terhadap pekerjaan yang dilakukannya. Keterlibatan juga dapat diartikan sebagai sebuah ukuran sampai dimana seseorang secara psikologis memihak pada pekerjaannya dan menganggap penting tingkat kinerja yang dicapai sebagai sebuah penghargaan diri. Bila karyawan memiliki tingkat keterlibatan yang tinggi pada pekerjaannya maka karyawan tersebut memiliki kepedulian yang tinggi pula. Faktor pendukung keterlibatan memastikan agar karyawan (1) memahami bagaimana departemen mereka berkontribusi pada kesuksesan perusahaan, (2) melihatbagaimana usaha mereka sendiri berkontribusi untuk mencapai sasaran perusahaan, dan (3) mendapatkan rasa pencapaian dari bekerja di perusahaan tersebut. Pemberi kerja harus juga memegang pertanggung jawaban manager untuk keterlibatan karyawan (Meliyanti, Dharmawan 2020).

(Simamora 2015) mendefinisikan kinerja sebagai ukuran hasil yang relevan dari prestasi kerja atau presatasi sesungguhnya yang dicapai oleh seorang karyawan. Perusahaan yang memiliki karyawan berprestasi maka besar kemungkinan memiliki tingkat kinerja yang baik, sehingga terdapat hubungan yang erat 
antara karyawan dan perusahaan karena kinerja perusahaan bergantung pada tingginya kinerja karyawan yang dihasilkan.

(M. Sinungan n.d.)Kinerja merupakan suatu istilah secara umum yang digunakan untuk sebagianatau seluruh tindakan atau aktivitas dari suatu organisasi pada suatu periodedengan referensi pada sejumlah standar seperti biaya-biaya masa lalu atauyang diproyeksikan, dengan dasar efisiensi, pertanggungjawaban atauakuntabilitas manajemen dan semacamnya. Kinerja merupakan suatu fungsi darimotivasi dan kemampuan. Menyelesaikan tugas atau pckcrjaan seseorangsepatutnya memiliki derajat kesediaan dan tingkat kemampuan tertentu. Kesediaan dan keterampilan seseorang tidaklah cukup efektif untukmengerjakan sesuatu tanpa pemahaman yang jelas tcntang apa yang akandikerjakan dan bagaimana mengerjakannya. Kinerja merupakan perilaku nyatayang (Wibowo 2017)

Kinerja adalah hasil kerja secara kualitas dan kuantitas yang dicapai olehseseorang pegawai dalam melaksanakan tugasnya sesuai dengan tanggung jawabyang diberikan kepadanya (Handoko 2001). Berdasarkan pemaparan daribeberapa teori di atas, maka dapat peneliti simpulkan bahwa kinerja merupakansuatu kondisi perilaku kerja yang harus diketahui dan dikonfirmasikan kepadapihak yang mempekerjakannya untuk mengetahui tingkat pencapaian dari suatuhasil kerja yang dihubungkan dengan tujuan yang diemban suatu perusahaan sertauntuk mengetahui suatu dampak positif dan negatif dari kebijakan yang dimilikiperusahaan tersebut.

\section{METODE PENELITIAN}

Penelitian ini mengambil sampel karyawan PT PLN (Persero) Rayon Talang Padang yang berlokasi di Jl. Raden Intan No.76, Suka Merindu, Talang Padang, Kabupaten Tanggamus, Lampung. Populasi adalah wilayah generalisasi yang terdiri atas subjek atau objek yang mempunyai kualitas dan karakteristik tertentu yang diterapkan oleh peneliti untuk dipelajari dan kemudian ditarik kesimpulannya (Arikunto, Suharsimi 2010). Populasi dari penelitian ini yaitu seluruh karyawan PT PLN (Persero) Rayon Talang Padang yang berjumlah 142 orang.

Analisis kuantitatif digunakan untuk mengetahui pengaruh kepemimpinan dan keterlibatan karyawan terhadap kinerja karyawan pada PT PLN Rayon Talang Padang dengan menggunakan rumus analisis regresi linier berganda.

Analisis ini digunakan untuk mengetahui pengaruh kepemimpinan dan keterlibatan karyawan terhadap kinerja karyawan pada PT PLN Rayon Talang Padang dengan menggunakan rumus analisis regresi linier sederhana:

$$
\begin{gathered}
Y=a+\beta 1 X 1+e \\
Y=a+\beta 2 X 2+e \\
Y=a+\beta 1 X 1+\beta 2 X 2+e
\end{gathered}
$$

Keterangan:

Y : Kinerja Karyawan

X1: Kepemimpinan

X2: Keterlibatan Karyawan

a : Konstanta

b1: koofisien X1

b2: koofisien X2

e :error 
Pengujian ini dimaksudkan untuk mengetahui secara parsial variabel independen berpengaruh signifikan terhadap variabel dependen, hipotesis yang diajukan adalah sebagai berikut :

- $\mathrm{H} 0: \mathrm{b} 1=0$, artinya secara parsial tidak terdapat pengaruh kepemimpinan terhadap kinerja karyawan.

- H1: $b 1 \neq 0$, artinya secara parsial terdapat pengaruh kepemimpinan terhadap kinerja karyawan.

- H0: b2=0, artinya secara parsial tidak terdapat pengaruh keterlibatan karyawan terhadap kinerja karyawan.

- H2: $\mathrm{b} 2 \neq 0$, artinya secara parsial terdapat pengaruh keterlibatan karyawan terhadap kinerja karyawan.

Dikatakan berpengaruh signifikan apabila sig $<\alpha(0,05)$, menggunakan rumus:

$$
t_{\text {hitung }}=\frac{b}{\partial b}
$$

Keterangan:

$\mathrm{b}$ : koofisien regresi variabel indpenden $\partial \mathrm{b}:$ standar deviasi koofisien regresi variabel independen

Pengujian ini dilakukan dengan tingkat keyakinan 95\% dengan ketentuan sebagai berikut:

- Jika t hitung \& gt; t tabel (0.05), maka hipotesis didukung.

- Jika t hitung \& 1t; t tabel (0.05), maka hipotesis tidak didukung.

Hasil uji $\mathrm{t}$ dapat dilihat pada Output Coefficient dari hasil analisis regresi linier berganda menggunakan SPSS.

\section{HASIL DAN PEMBAHASAN}

\begin{tabular}{|c|c|c|c|c|c|}
\hline \multicolumn{6}{|c|}{$\begin{array}{c}\text { Ringkasan Hasil Uji t } \\
\text { Coefficientsa }\end{array}$} \\
\hline \multirow[t]{2}{*}{ Model } & \multicolumn{2}{|c|}{$\begin{array}{l}\text { Unstandardized } \\
\text { Coefficients }\end{array}$} & \multirow[t]{2}{*}{$\begin{array}{l}\text { Standardized } \\
\text { Coefficients }\end{array}$} & \multirow[t]{2}{*}{$\mathrm{T}$} & \multirow[t]{2}{*}{ Sig. } \\
\hline & B & Std. Error & & & \\
\hline $\begin{array}{l}\text { (Constan } \\
\text { t) }\end{array}$ & ${ }^{1} 65,726$ & 5,260 & & 12,496 & 0,000 \\
\hline $1 \times 1$ & 0,214 & 0,077 & 0,274 & 2,780 & 0,006 \\
\hline $\mathrm{x} 2$ & 0,763 & 0,205 & 0,368 & 3,725 & 0,000 \\
\hline
\end{tabular}

Pengaruh kepemimpinan terhadap kinerja karyawan PT PLN Rayon Talang Padang. Hasil penelitian yang terdapat pada Tabel 4.21 diperoleh t sebesar 2,780. Nilai sig, sebesar $0,06<0,05$, maka H1 diterima dan Ho ditolak. Dapat disimpulkan bahwa variabel X1 memiliki kontribusi terhadap $Y$. Nilai $t$ positif menunjukkan bahwa variabel $\mathrm{X} 1$ mempunyai hubungan yang searah dengan Y. Jadi dapat disimpulkan kepemimpinan berpengaruh positif dan signifikan terhadap Kinerja Karyawan PT PLN Rayon Talang Padang. Dimana semakin baik kepemimpinan maka akan semakin tinggi kinerja karyawan.

Kepemimpinan (leadership) dapat dikatakan sebagai cara dari seorang pemimpin (leader) dalam mengarahkan, mendorong dan mengatur seluruh unsurunsur di dalam kelompok atau organisasinya untuk mencapai suatu tujuan organisasi yang diinginkan sehingga menghasilkan kinerja pegawai yang maksimal. Dengan meningkatnya kinerja pegawai berarti tercapainya hasil kerja seseorang atau pegawai dalam mewujudkan tujuan organisasi.

Di setiap organisasi pasti ada pemimpin dan dipimpin. Pemimpin harus berhubungan baik dengan siapa saja yang dipimpinnya. Pemimpin harus mengenal dan mengetahui orang-orang yang ia pimpin dalam suatu organisasi. Pemimpin pun bertanggung jawab akan semua hal yang menyangkut organisasi yang ia jalankan. Organisasi akan berjalan dengan 
baik, ketika peran kepemimpinan dalam sebuah organisasi itu dijalankan dengan sebaik - baiknya dan penuh dengan tanggung jawab namun sebaliknya, jika peran kepemimpinan tidak dilaksanakan sesuai dengan aturan main yang ada maka akan timbul berbagai persoalan yang dapat menghambat atau mempengaruhi kinerja orang - orang yang dipimpinnya.

Gambaran tersebut terlihat dengan jelas bahwa kemajuan dan kemunduran suatu organisasi tergantung dari kualitas kepemimpinan seorang pemimpin. Dilihat dari sudut pandang apapun juga pemimpin selalu ditempatkan pada satu titik yang sangat penting. Peran seorang pemimpin dalam satu organisasi atau kelompok sangatlah vital. Karena dalam perannya tersebut, seorang pemimpin akan membantu organisasi untuk mewujudkan visi dan misinya. Oleh sebab itu, efektifitas seorang pemimpin didalam menggunakan pengaruh - pengaruhnya sangat menentukan bagaimana pemimpin tersebut dapat memainkan perannya dengan baik. Untuk itu, pemimpin selalu harus diasah dan dikembangkan, sehingga dapat menyesuaikan diri dengan situasi - situasi yang dihadapinya. Baik situasi itu berasal dari anak buah, atasan ataupun organisasi di mana ia berada. Dilihat disini pentingnya seorang pemimpin pada saat melaksanakan kepemimpinannya dapat memberdayakan dirinya sendiri sebelum memberdayakan orang lain. Dalam ranah kepemimpinan ada tiga hal yang harus dikembangkan oleh seorang pemimpin yakni seorang pemimpin harus mampu memimpin diri sendiri (managing self), memimpin orang (managing people), dan memimpin tugas (managing job).

Terujinya hipotesis tersebut, maka dengan demikian hasil penelitian ini mendukung pendapat teoritis atau pun hasil-hasil kajian penelitian yang pernah dilakukan para ahli. Menurut Siagian (2003) kepemimpinanlah yang memainkan peranan yang sangat dominan dalam keberhasilan organisasi dalam menyelenggarakan berbagai kegiatannya terutama terlihat dalam kinerja para pegawainya yang dapat dilihat dari bagaimana seorang pemimpin dapat mempengaruhi bawahannya untuk bekerjasama menghasilkan pekerjaan yang efektif dan efisien. Tangkilisan (2005) pemimpin yang efektif harus mempunyai agenda dalam mencapai tujuan organisasi, menghadapi tantangan dan kemungkinan yang akan terjadi dan mewujudkan keinginannya dengan visi baru serta mengomunikasikanya dan mengajak bawahan bersatu untuk mencapai tujuan baru dengan menggunakan sumber daya dan energi seefisien mungkin.

Berkaitan dengan hasil penelitian ini maka mendukung penelitian yang dilakukan oleh Kurniawan, (2013). Hasil penelitian ini menunjukkan bahwa variabel kepemimpinan berpengaruh positif dan signifikan terhadap kinerja dan variabel remunerasi tidak berpengaruh signifikan terhadap kinerja.

Pengaruh keterlibatan karyawan terhadap kinerja karyawan PT PLN Rayon Talang Padang. Hasil penelitian yang terdapat pada Tabel 4.18 diperoleh $\mathrm{t}$ sebesar 3,725 Nilai sig, sebesar $0,000<0,05$, maka variabel X2 mempunyai t-hitung sebesar 4,568 dengan t-tabel= 1,660. Nilai t positif menunjukkan bahwa variabel $\mathrm{X} 2$ mempunyai hubungan yang searah dengan Y. Jadi dapat disimpulkan keterlibatan berpengaruh positif dan signifikan terhadap Kinerja Karyawan PT PLN Rayon Talang Padang, dimana semakin tinggi keterlibatan maka semakin tinggi kinerja karyawan.

Kemampuan karyawan dalam menerapkan ilmu melalui kecerdasan intelektual yang dimilikinya yang diterapkan dalam pekerjaan akan menghasilkan kinerja dalam pekerjaannya. Keterlibatan kerja tersebut misalnya 
ditunjukan dengan menyumbangkan ide untuk kemajuan pekerjaan, dengan senang hati mematuhi peraturan-peraturan perusahaan dan mendukung kebijakan perusahaan.

Keterlibatan kerja yang rendah pada diri karyawan berakibat pada kurangnya komitmen karyawan terhadap organisasi yang berakibat pada tingkat kinerja yang rendah yang ditunjukan oleh karyawan. Karyawan beranggapan bahwa partisipasi mereka tidak terlalu dibutuhkan oleh perusahaan. Situasi tersebut tidak dapat membantu dalam pemuasan kebutuhan seorang karyawan akan tanggung jawab, prestasi, pengakuan, dan peningkatan harga diri

Hasil uji signifikansi koefisien regresi secara parsial penelitian ini menunjukkan bahwa keterlibatan berpengaruh positif signifikan terhadap kinerja. Penelitian ini menjelaskan bahwa keterlibatan kerja mampu menjadi salah satu faktor yang dapat meningkatkan kinerja karyawan. Semakin tinggi keterlibatan kerja maka semakin meningkat pula kinerja atau sebaliknya. Semakin banyak seseorang terlibat dalam pekerjaannya akan semakin dihargai baik oleh atasan maupun rekan sekerja, jadi akan memotivasi untuk berkompetisi. Semakin tinggi kompetisi antar individu akan memakin meningkatkan kinerja. Hasil penelitian ini sejalan dengan penelitian yang dilakukan oleh Chugtai (2008) yang menyatakan bahwa keterlibatan kerja berpengaruh positif dan signifikan, dan memiliki pengaruh yang sangat tinggi terhadap kinerja. Sehingga mendorong tingkat keterlibatan kerja karyawan dapat menjadi strategi yang efektif untuk meningkatkan kinerja.

(S.B. Nasir 2011), (Safira S. 2013) dan (Danish, Q.R., Shahid, A.U., Aslam, N., Afzal, M., Ali, H.Y 2015) . Keempat hasil penelitian terdahulu tersebut menemukan bahwa keterlibatan kerja berpengaruh positif dan signifikan terhadap kinerja. Dengan adanya hal tersebut penulis menyimpulkan bahwa organisasi dapat mempertahankan tingkat keterlibatan kerja karyawan yang sudah ada menjadi lebih tinggi, dengan cara mendorong partisiasi aktif dari diri karyawan, meningkatan rasa terlibat pada pekerjaan yang dilakukan, serta memberikan nilai kepada karyawan bahwa pekerjaan penting bagi harga diri karyawan.

\section{PENUTUP}

\section{A. Kesimpulan}

Hasil penelitian yang dilakukan diperoleh kesimpulan bahwa penelitian ini mendukung hipotesis yang di ajukan:

1. Kepemimpinan berpengaruh positif dan signifikan terhadap kinerja karyawan PT PLN Rayon Talang Padang dimana semakin baik kepemimpinan maka semakin tinggi kinerja karyawan.

2. Keterlibatan karyawan pengaruh yang positif dan signifikan terhadap kinerja karyawan PT PLN Rayon Talang Padang maka semakin tinggi keterlibatan karyawan maka semakin baik kinerja karyawan.

\section{B. Saran}

1. Bagi Perusahaan

Hasil penelitin penunjukan terbukti bahwa kepemimpinandan keterlibatan terhadap kinerja karyawan berpengaruh signifikan, sementara hasil deskriptif masih terdapat karyawan yang memiliki kinerja karyawan yang rendah maka disarankan bagi perusahaan untuk dapat memperhatikan kesejahteraan 
karyawan sehingga terjadi kepuasan yang akan berdampak pada produktifitas perusahaan.

2. Bagi Karyawan

Hasil penelitian menunjukkan masih memiliki keterlibatan karyawan yang rendah disarankan untuk dapat meningkatkan keterlibatannya dalam pekerjaan yang dikuasai karena semakin banyak seseorang terlibat dalam pekerjaannya akan semakin dihargai baik oleh atasan maupun rekan sekerja, jadi akan memotivasi untuk berkompetisi.

3. Bagi peneliti selanjutnya

Untuk penelitian selanjutnya, disarankan menambahkan kompenen lain dalam penelitian selanjutnya ,seperti pengaruh kecerdasasan emosinal, kecerdasan intelektual, dan kecerdasan spiritual dalam pengaruhnya terhadap kinerja.

\section{DAFTAR PUSTAKA}

Aprianis. 2020. Manajemen Sumber Daya Manusia. Bandar Lampung: Saburai Press.

Arikunto, Suharsimi. 2010. Prosedur Penelitian. Jakarta: Rineka Cipta.

Danish, Q.R., Shahid, A.U., Aslam, N., Afzal, M., Ali, H.Y. 2015. "Relationship between Job Performance, Job Involvement, and Career Salience of Employees in Education Sector of Pakistan." American Journal of Educational Science.

Dharmawan, Aprianis. 2020. "EFFECT OF LEADERSHIP AND ORGANIZATIONAL CULTURE
ON EMPLOYEE PERFORMANCE IN CLASS II OFFICIAL OFFICES OF REZA BERAWI KOTA BANDAR LAMPUNG." SABURAI INTERNASIONAL JOURNAL OF SOCIAL SCIENCES AND DEVELOPMENT 4(2):77-86.

Handoko. 2001. Pelatihan Dan Pengembangan. Alfabet: Bandung.

M. Sinungan. n.d. "Pengaruh Disiplin Terhadap Kinerja. PT. Rakatama Putra Gegana Bandung." Universitas Winaya Mukti Bandung.

Malayu .S.P. Hasibuan. 2001. Manajemen Dasar. Jakarta: Bumi Aksara.

Malayu .S.P. Hasibuan. 2013. Manajemen Sumber Daya Manusia. Jakarta: Bumi Aksara.

Meliyanti, Dharmawan. 2020. "PENGARUH MOTIVASI DAN DISIPLIN KERJA TERHADAP KINERJA PEGAWAI PADA KANTOR BADAN PENGELOLA PAJAK DAN RETRIBUSI DAERAH KABUPATEN LAMPUNG SELATAN." Jurnal Ilmu Manajemen Saburai (JIMS) 6(2):101-10.

P Stephen \& Coutler Robbins. 2016. "Human Resources Management." in Vol. 1. Jakarta: Salemba empat.

Safira S. 2013. "Pengaruh Keterlibatan Kerja Terhadap Kinerja Pegawai Pada PT Seascape Surveys Indonesia." E-Journal Manajemen Dan Bisnis.

S.B. Nasir. 2011. "The Impact of Job Involvement, Reward System on Empoyee Job Performance." Elexir International Journal. 
Simamora, H. 2015. Manajemen Sumber Daya Manusia. III. Yogyakarta: STIE YKPN.

Trisnowati Josiah. 2021. Manajerial Budaya Organisasi, Kepemimpinan, Dan Kinerja. Bandar Lampung: Saburai Press.

Wibowo, Wibowo. 2017. MANAJEMEN KINERJA. IV. Jakarta. 